\title{
The Border Area Conflict Impact on Government Responsiveness Relating on Public Service
}

\author{
Eny Boedi Orbawati ${ }^{1}$, Sri Suwitri, Yuwanto ${ }^{2}$ \\ 1,2Universitas Diponegoro, J1. Prof. H. Soedarto, S.H. Tembalang, 50275, Indonesia
}

\begin{abstract}
Responsiveness or response are the desire and the will of the bureaucracy in the expectations, desires and aspirations and demands of the community services provided quickly and responsively. The responsiveness of government bureaucracy needs to be done across Government jurisdictions begin from the Central Government to the border region. However, the occurrence of conflict affirmation borders of Magelang regencies and cities affected the responsiveness of regional pemerinrah in the service of public administration services in particular resistance. This research aims to describe and determine the factors affecting the responsiveness of local governments in implementing public service in conflict areas and County boundary affirmation in Magelang city. The methods used in this research is a mix of qualitative and quantitative approaches are converging. Data collection is done by survey, interview and documentation. Qualitative data analysis done through interactive model with the validity methodology of the analysis focuses on the triangulation, with rolling according to needs also use techniques of the other validity. The research's results show that the local government County and Magelang city has not been responsive in public services on the territory of the conflict area limits the visible affirmations of public service obstrction of the administration of land in the region. Yet the responsiveness of the local government in the public service is affected by the problem complexity, Government regulatory authorities and the County and Magelang City, leadership of public officials who are not able to listen to the grievances of the public and the haven't priority of the broader public interest in making the corresponding decisions of public service in the area of the disputed boundary area.
\end{abstract}

\section{Keywords: Responsiveness; Public Service; Disputed Boundary Area}

\section{Introduction}

The responsiveness of Government became very important in conducting Government of the region, but there are constraints within the Ministry of the public in the conflict area of affirmation limit areas.. . The issue of regional boundary and limit quantities autonomous region is crucial for the effectiveness of local governance. Norton [1] reveals that this area limit setup with regards to economic efficiency, the effectiveness of democracy and the efficiency of public services. Determination of the limits of the areas of vagueness so as to result in the public service against the obstructipon from people who live in the area of conflict affirmation. As conflict affirmation borders of magelang County and City.

The responsive bureaucracy have to be reactive, sympathetic, sensitive and able to feel the needs and opinions of the public [2]. However, the occurrence of conflict affirmation borders of Magelang County and City are affected the responsiveness of local government into public administration services in particular of boundary.
People living in Bulurejo village of Magelang County recognized also as the citizens of the Jurangombo District the South of Magelang City.. In the population administration they classify as residents of Magelang City, but in the administration of land, their area of Bulurejo village of Magelang County. So they are having difficulties in getting the land administration services. The existence of conflicts of the area's boundaries resulted in the affirmation of local governments could not meet what the complaints, problems and aspirations of the community.

Gormley, Hoadley, and Williams ${ }^{3}$ defined as the ability of the responsiveness of Government to establish quickly the important issues that must be addressed immediately, addressing the issues and problems for real with a variety of actions, through the provision of a wide range of resources. Potential responsiveness in halini is an overview of the extent to which local governments with the stakeholders assign together to identify the problems of public service in the area of dispute, involving stakeholders in discussion of the issues and developing an 
alternative solution (or program activities) that corresponds to the issue of public services in the area of boundary disputes [3].

Actual responsiveness refers to the extent to which the Government is able to meet the needs and desires of society as real in its actions. A variety of problems, needs and wants of the community which has been expressed in the potential responsiveness then quickly needs to be followed up through actions or programs that can directly tackle the issue. Esaiasson, Gilljam and Persson [4] identified three important things in action (actual) Government responsiveness, among other things: (1) To listen, that the action taken by the Government to obtain information on the sentiment, mood, or discourse the direction of public opinion about a problem (actions taken to stay informed about citizen sentiment); (2) To explain, that the action taken by the Government to provide a credible justification or reasoning for such a Government policy decisions taken in the face of a certain public issues; (3) To adapt that is Government action taken to adjust or align Government policy decisions taken by a majority of the public opinion's direction.

The Government can be said to be responsive when they create and implement policies that are desired by the citizens of the Community [5]. View of Powell that contains the elements of the concept of the responsiveness of government bureaucracy that is what was done (to what) of an elected public official (what from) to meet or answer the demands of the people (to whom).

\section{Methodology}

The methods used in this research is a mix of qualitative and quantitative approaches are converging. Data collection is done by survey, interview and documentation. Qualitative data analysis done interactive model with the validity methodology of analysis focusing on triangulation source, with the source and this means to compare and check behind the degree of trust an information gained through time and different tools in qualitative research.

\section{Discussion}

\subsection{Potential Effort}

\subsubsection{Power Capability of the Government in the process of Problem Identification}

Research results have shown that assertion borders of Magelang County and City is not new, but the issues are already underway in years. The dispute resolution process had stalled over the years. This shows that the District Government and Magelang city has not been utmost in focusing the public service issues in the area of dispute the assertion of regional and priority limits become an urgent public matter to be handled and found the solution its policies.

The local Government has not been able to identify properly what the complaints and concerns of the community, namely public services in conflict areas affirmation limit area. The inability of the local authorities in identifying the issue of public services in the area of boundary disputes in a comprehensive manner, more due to the limited information obtained from one party, namely the Government's own internal party and yet involve all elements of the community with regard to the dispute over the boundaries of the region. Therefore, the ability of local governments in identifying the problem to ensure the passage of the public service in the territory of the regional boundary disputes can be done with maximize and focus the public on the discussion issues and interests a wider public for the sake of the passage of the public service in the area of dispute the assertion of the limits of the area.

\subsubsection{Stakeholders Involvement}

The results showed that the local governments have yet to involve elements of the local community and the other parties in the discussion of the issues surrounding public services in areas of conflict. The Government also has yet to involve other parties outside of Government (academics, political figures, CBOs, NGOs, etc.) in the discussion of the issues surrounding public services in areas of conflict. Whereas the involvement of stakeholders is essential for the Government to do. This is in line with the opinion of the Burgess [6] suggests that is important to bring in or involve more parties (stakeholders) in the process of public policy and the public interest varied dispersion will be beneficial to generate public policy jointly.

\subsection{Actual Responsiveness}

\subsubsection{To listen}

The results of the survey and interviews showed that the majority of respondents stated the Government's existing do not hear what complained and demanded by the society on the issue of public services in the area of the disputed boundary area. Beside that less Government understands well the demands of the public on issues of public service in the area of the disputed boundary area. The Government has not fully capable of understanding the complaint nor the will of the people this is because each Government has its own legal basis and arguments. Magelang City Government requires the existence of a territorial expansion. While the Magelang County willed assertion borders.

\subsubsection{To explain}

Responsiveness of actual Government belongs to low because based on the dimension is 
visible from the survey to explain, that the local authorities are not able to give an explanation to the public obstruction of public services on the territory of the disputed boundary area. While it was also found that local governments were not able to provide information to the public through the mass media on the subject of public services in the area of the disputed boundary area. Paint related explanation of the Government in service to the community is still lacking, this is evidenced by the complaints of the difficulty of getting access to the service.

\subsubsection{To adapt}

Responsiveness of actual Government belongs to low because based on the dimension is visible from the survey to explain, that local governments do not apply special facilities for public services in the region of the conflict. The local Government also organizes activities not specifically who can bridge the public services obstruction on the territory dispute over the boundaries of the region. Based on that data, it appears that the public perceive that the local authorities lack to respond and follow up an issue with a particular program or activity. That is, there is no special priority in a program or activity for the community in the area of conflict in the service area boundary of the affirmation of the permissions.

The slowness of the response given by the Government to resolve the conflict between the affirmation of Magelang County and Magelang City, have an impact on the existence of a real effort yet undertaken local governments in dealing with the problem of public service in the area of the conflict. Programs or activities already in existence has not yet been able to answer all the problems that exist. If the main problem area boundary affirmation conflict there has not been an agreement from the two regions to the dispute, then the Government itself still has not been able to answer the question of public service.

\subsection{Factors affecting the responsiveness of Local Government in the Public Service in the Area of District Boundary Disputes of Magelang County and City}

\subsubsection{The Leadership of Government Official}

Research results show that the leadership of the head of the region could not able solving the issue of public service area boundary conflicts. Support the leadership of public officials is reflected in the numerous attempts of conflict resolution limit of the territory already held by either the Government of Magelang County or City. Based on the interviews can be obtained information that the leadership of the head area and other public officials have not been fullest in tackling the problems of public service area boundary conflict has not yet be resolved.

\subsubsection{The Regulation Authority}

The Government has the authority or the obligation in solving conflict area of public service conflict issue limit.. According to interview with the head of Government of Magelang City that neither County nor the Magelang City has sought to do problem solving the conflict borders the County and Magelang City. Various regulations have been published to support the process of the conflict settlement, but until now has not yet reached an agreement.

Refers to a variety of regulations that have been published by the Central Government, the regulatory framework in principle has supported the process of conflict resolution. The Central Government has provided facilitation and discretion to the parties for the settlement of the conflict. Each stage and the problems of specially facilitated through the provincial government to find the best solution for all parties. The Central Government has given the leeway to both parties to find the best solution for the sake of organizing public services provided in the area of the conflict area boundary affirmation regencies and cities. However, precisely because such regulations provide facilitation and discretion to the parties to find an agreement and the best deal, then the process of conflict resolution be hampered because understanding and agreement between the parties failed to achieved, due to disagreements on a sharp argument. In addition, the lack of political will from the parties participated and led to regulatory aspects have not been able to be optimal in supporting conflict resolution an affirmation of the regional boundaries of Counties and Magelang City.

\subsubsection{Problems Complexities}

The problems complexities are the level of problems that occur in an object of research. The issue of public service area boundary conflict is very complex and need special attention from the Government, not just the local government but also the provinces and the Central Government. The issue of public services needs to limit conflict involving the whole elements of Government and society. The settlement of conflicts in the border areas carried out by the Government of the County and Magelang City in order to make the public service a better yet, very awaited by society or company parties that wish to take care of licensing in the border areas. Based on the results of the interview are can be obtained information that the problem in the public service in the area of dispute over this limit is very complex.

\subsubsection{Public Orientation}

On the results of this survey indicate that mainstreaming public interest in handling the issue of public services on the territory of the regional boundary disputes still belongs to low. Based on the 
survey data to see that most of the public opinion that the Government has not yet completely responsive to complaints from the public. Complaints and demands that come from the community regarding the public service that has not been satisfactory, actually is a problem that should be dug and searched for a solution by the Government. But for now the party of the Government itself has yet to dig into problems of public service that appears as a result of not yet terselesainya affirmation limit conflict between the County and Magelang City. So, it can be ascertained that there has been no definite efforts undertaken by the Government in the fulfilment of the public service in the area of border dispute.

The lack of response from the Government on the demands of society towards the services provided, then it is also coupled with no effort from the Government concerning the fulfillment of the Ministry as the Government itself has not yet been dug the service problems. To be able to meet and give good service and should be in accordance with the demands of the community, then local governments seeking the real steps to resolve conflicts affirmation of territorial boundaries.

\section{Conclusion}

Potential responsiveness of local government which is described in the ability of local governments in public service issues quickly identify in conflict areas and limits the involvement of affirmation stakeholders in discussing issues and develop alternative solutions in accordance with the public service issues in the area of the disputed region is still low limit.

Actual responsiveness of local government in the service of the public in the area of the disputed boundary area is still low. Responsiveness to actual local Government identified of (1) To listen, that the action taken by the Government to obtain information on the sentiment, the mood, the discourse or the direction of public opinion about a problem (actions taken to stay informed about citizen sentiment); (2) To explain, that the action taken by the Government to provide a credible justification or reasoning for such a Government policy decisions taken in the face of a certain public issues; (3) To adapt that is Government action taken to adapt or harmonise the policy decisions taken with government majority public opinion direction.

To improve the responsiveness of local government in the service of the public in the area of the disputed boundary area needs to develop listening bureaucracy and bring a collaborative action.

If responsiveness potential and actual responsiveness supported by developing listening bureaucracy and bring a collaborative action is good then responsifitas Government in the service of the public in the area of the disputed boundary area will be good.

Corresponding author email: enyorbawati@gmail.com
Enviroment issues on the border conflicts could somehow become a lack of response from goverment due to low-interest to enviroment issues, thus gaining tempered on the border conflict caused by civil unrest related to enviroment damages in border area.

\section{References and Notes}

1. A. Norton, International hand books of Local and Regional Government : a Comparative Analysis of Advanced Democracies. Cheltenham : Edwar Elgar (1994).

2. E. Vigoda, "From Responsiveness to Collaboration: Governance, Citizens, and the Next Generation of Public Administration". Public Administration Review, 62(5): 527-540 (2002).

3. W. Gormley, J. Hoadley, C. Williams, "Potential Responsiveness in the Bureaucracy: Views of Public Utility Regulation", The American (Politica Science Review vol 77 no 3 (September 1983), pp 704 - 717 (1983).

4. P. Esaiasson, M. Gilljam \& M. Persson. "Responsiveness Beyond Policy Satisfaction: Does It Matter to Citizens?". Comparative Political Studies: 1 -27 (2016).

5. G. Powell, "The chain of responsiveness". Journal of Democracy, 15, 91-105 (2004).

6. M. M. Burgess, "From trust us to participatory governance: deliberative publics and science policy". Public Understending of Science, 23: 48-52 (2014). 